\title{
NEW SOCIAL CAPITAL DAN REVOLUSI INDUSTRI 4.0; STUDI TERHADAP PEMBANGUNAN MASYARAKAT UMKM BATIK TANJUNG BUMI BANGKALAN MADURA
}

\author{
Khoirul Rosyadi \\ Program Studi Sosiologi Fakultas IImu Sosial dan IImu Budaya \\ Universitas Trunojoyo Madura \\ E-mail : khorosid@gmail.com
}

http://doi.org/10.21107/pmt.v11i2.4772

\begin{abstract}
Abstrak
Modal Sosial merupakan, modal diluar modal ekonomi, yang secara fungsional berperan sebagai alat untuk membangun setiap apa yang dicitakan. Modal sosial meningkatkan kemungkinan individu untuk bekerjasama dan memberikan kemajuan secara umum pada kualitas hidup. Disamping itu modal sosial meningkatkan efisiensi sosial dengan cara memfasilitasi aksi-aksi yang terkoordinasi. UMKM adalah penyanggah ekonomi di negeri ini. Dalam konteks ini, UMKM Batik Tanjung Bumi Bangkalan Madura adalah bagian UMKM yang selama ini menjadi fundamental ekonomi masyarakat, khususnya di daerah Bangkalan Madura. Salah satu yang menjadikan UMKM Batik Tanjung Bumi Bangjkalan Madura bisa bertahan sampai hari ini adalah kekuatan modal sosial yang mereka miliki. Tidak ada jalan pilihan lain bagi UMKM Batik Tanjung Bumi, Bangkalan, Bangkalan untuk aktif dalam ekonomi digital. Hanya dengan itu UMKM Batik Tanjung Bumi akan bisa bertahan dan melakukan akselarisasi ekonomi yang luas.
\end{abstract}

Kata Kunci : UMKM Batik, Tanjung Bumi, modal sosial, ekonomi

\section{PENDAHULUAN}

Memasuki era digital, semuanya telah berubah. Tidak terkecuali dalam bidang ekonomi. Hari ini kita menjumpai bahwa semua bidang kehidupan khususnya, bidang ekonomi digerakkan oleh teknologi dan informasi. Hal ini yang menandainya dimulainya era revolusi industry 4.0. Salah satu konsekuensi dari revolusi industry 4.0 tersut adalah lahirnya proses digitalisasi dalam segala bidang. Pun dalam bidang ekonomi. Digitalisasi ekonomi kemudian menjadi salah satu keniscayaan di era revolusi 4.0.

Fakta itulah yang menjadikan paradigma tentang ekonomi dan marketing juga berubah. Produksi, distribusi, hingga pemasaran harus mengikuti gerak digitaliasi ekonomi dunia yang terus berkembang. Tentu perubahan membawa sesuatu baru yang menguntung bagi pelaku ekonomi. Hari ini faktor ekonomi semua bergerak menuju digitaliasi ekonomi dengan menekankan kekuatan teknologi dan informasi. Jangkauan luas dan kecematan yang signifikan menjadi keunggulan digitalisasi ekonomi tersebut.

Aktor ekonomi tersebut, juga terjadi pada akhirnya juga akan terjadi pada UKM (usaha kecil menengah) di Indonesia, termasuk pelaku UMKM Batik di Tanjung Bumi, Bangkalan, Madura. Tidak ada jalan pilihan lain bagi UMKM Batik Tanjung Bumi, Bangkalan, Bangkalan untuk aktif dalam ekonomi digital. Hanya dengan itu UMKM Batik Tanjung Bumi akan bisa bertahan dan melakukan akselarisasi ekonomi yang luas. Karenanya yang dibutuhkan UMKM Batik Tanjung Bumi, Bangkalan Madura, bagaimana mereka memiliki knowledge terkait dengan ekonomi digital. Untuk itu penguasaan terhadap internet, kemampuan akan media sosial, hingga kemampuan membangun jaringan harus diberikan. Oleh karena itu dibutuhkan pendampingan terhadap para pelaku UMKM Batik Tanjung Bumi, Bangkalan, Madura.

\section{Modal Sosial dan New Social Capital}

Modal Sosial seperti yang dipahami merupakan, modal diluar modal ekonomi, 
yang secara fungsional berperan sebagai alat untuk membangun setiap apa yang dicitakan. Dalam bahasa Francis Fukuyama (2002) berpendapat bahwa modal sosial dapat diartikan sebagai sumber daya, baik yang tampak maupun yang tidak tampak yang dimiliki individu maupun kelompok yang digunakan untuk proses kerjasama yang saling menguntungkan dan dipahami bersama. Ditambahkan pula bahwa civil society seharusnya memiliki modal sosial sebagai norma dan nilai yang digunakan dalam kerjasama kelompok.

Menurut Woolcock (1998), modal sosial meningkatkan kemungkinan individu untuk bekerjasama dan memberikan kemajuan secara umum pada kualitas hidup. Disamping itu modal sosial meningkatkan efisiensi sosial dengan cara memfasilitasi aksi-aksi yang terkoordinasi. Ada enam hal yang berkaitan dengan modal sosial yaitu :

1. Partisipasi dalam kerjasama

Partisipasi dalam suatu kerjasama ditujukan untuk mengurangi hambatanhambatan dalam hubungan sosial dan antara individu dan kelompok.

2. Hubungan timbal balik

Dalam suatu komunitas dimana hubungan timbal balik tersebut kuat, antar individu saling memperhatikan kepentingan setiap individu.

3. Kepercayaan

Kepercayaan memunculkan kehendak untuk mengambil resiko dalam sebuah konteks sosial yang berdasar pada rasa kepercayaan bahwa orang lain akan merespon seperti yang diharapkan dan bertindak dengan cara yang mendukung dan menguntungkan atau minimal tidak bermaksud untuk menentang.

4. Norma-norma sosial

Norma-norma sosial memberikan sebuah bentuk dari kontrol sosial informal yang dapat menutupi kekurangan sanksi-sanksi dari kontrol formal. Norma sosial dipahami dan diartikan sebagai perilaku yang diharapkan dalam sebuah konteks sosial untuk selanjutnya menentukan bentuk perilaku yang bernilai atau yang diharapkan.
5. Kebersamaan

Merupakan kombinasi efek kerjasama, kepercayaan, norma dan hubungan timbal balik yang menciptakan komunitas yang kuat. Kebersamaan merupakan kreasi dari sumber daya yang menyatukan komunitas, dan sumber daya tersebut tidak dimiliki oleh setiap anggota komunitas, tetapi digunakan bersama.

6. Pro-aktif

Perasaan dari setiap individu akan keikutsertaannya dalam kelompok. Perkembangan modal sosial ditunjukkan dalam keaktifan dan kehendak warga negara untuk berpartisipasi dalam komunitas.

Dalam pendekatan praktis, Woolcock (1998) mengemukakan beberapa komponen dari social capital, yaitu: bonding (contoh : keluarga, teman dekat). Bridging (contoh : jaringan luas dalam suatu komunitas). Linking (contoh: institusiinstitusi, bisnis, dan pemerintah). Menurut The Asia Foundation (1998) modal sosial merupakan hasil interaksi dari sumber daya pengetahuan dan identitas yang secara simultan digunakan dan dibangun dalam suatu proses belajar. Sumber daya eksternal meliputi hubungan internal dan eksternal dengan komunitas, keterampilan dan pengetahuan, komunikasi, nilai yang menjadi atribut dari komunitas. Sedangkan sumber daya identitas meliputi atribut kognitif dan afektif, yang terdiri dari self confidence sikap terhadap norma dan nilai, visi, kepercayaan, komitmen terhadap komunitas. Baik sumber daya pengetahuan maupun sumber daya identitas akan berinteraksi menjadi perilaku yang kooperatif terhadap komunitas untuk menghasilkan keuntungan bagi komunitas tersebut.

Menurut Hidayat (2001) modal sosial merupakan sesuatu yang dapat dilihat secara nyata, termasuk didalamnya partisipasi dalam pengambil kebijakan, protokol profesional, belajar sosial, kolaborasi, kepercayaan dan solusi terhadap permasalahan-permasalahn umum, tanggung jawab secara kolektif. Ditambahkan oleh Hidayat (2001) bahwa modal sosial adalah alat untuk memberikan 
kontrol terhadap tingkah laku, sehingga merupakan sebuah sumber daya yang diperlukan dalam kehidupan sosial.

Berdasar kajian teori diatas, modal sosial adalah sumber daya yang mendorong individu untuk mampu melakukan hubungan sosial secara efektif berdasarkan atas kepercayaan, norma , prinsip saling menguntungkan, kebersamaan, partisipasi aktif, dan proaktif sehingga meningkatkan kemampuan pemecahan masalah dan kualitas hidup. Sementera itu kelompok adalah agregat sosial dimana anggota-anggota yang saling tergantung dan setidak-tidaknya memiliki potensi untuk melakukan interaksi satu sama lain. Kelompok yang dalam hal ini merujuk pada para pengrajin batik tulis di desa Tanjung Bumi, Paseseh, dan Telaga Biru, baik pemodal besar maupun pemodal kecil. Mereka adalah sekelompok orang yang secara teratur berinteraksi dalam kaitannya dengan aktivitas atau tujuan tertentu (aktivitas ekonomi).

Pada beberapa kelompok, ikatan diantara anggota-anggota kuat dan menetap. Pada kelompok lain, ikatan tersebut kendur dengan hilangnya rasa "berkelompok" dan semakin lama anggotaanggotanya cenderung memisahkan diri. Kekompakan mengacu pada kekuatan, baik positif maupun negatif, yang menyebabkan para anggota menetap pada suatu kelompok (Woolcock, 1998). Kekompakan merupakan karakteristik kelompok sebagai suatu kesatuan. Ini bergantung pada tingkat keterikatan individual yang dimiliki setiap anggota kelompok.

Daya tarik antar pribadi yang terdapat diantara anggota kelompok merupakan kekuatan pokok yang positif (Taylor, 1994). Pertama, bila anggota kelompok dieratkan dengan ikatan persahabatan, kekompakan kelompok itu akan tinggi. Kedua, kekompakan kelompok juga dipengaruhi oleh tujuan instrumental kelompok itu. Ketertarikan seseorang terhadap suatu kelompok bergantung pada kesesuaian antara kebutuhan dan tujuan kita sendiri dengan kegiatan dan tujuan kelompok.

Faktor ketiga adalah sejauh mana suatu kelompok berinteraksi secara efektif dan selaras. Pada umumnya, segala sesuatu yang meningkatkan kepuasan dan semangat kelompok akan meningkatkan kekompakan. Kekompakan kelompok juga dipengaruhi oleh kekuatan negatif yang menyebabkan para anggotanya tidak berani meninggalkan kelompok itu, bahkan mereka merasa tidak puas.

Sementara dalam dinamika modal sosial dalam praktek ekonomi, Lingkup modal sosial dalam pengembangan UKM menurut Carrier R. Leana \& Van Burren, seperti yang dikutip Mubyarto (1994) adalah:

1. Associability. Dalam lingkup ini, yang dilihat adalah apakah kelompok yang bersangkutan memiliki kemampuan melakukan interaksi sosial dibarengi dengan kemampuan memacu aksi kolektif yang memadai dalam usahausaha Bersama;

2. Shared trust. Maksudnya adalah adanya kepercayaan timbal balik dalam usaha kolektif;

3. Shared responsibility. Adanya tanggung jawab bersama untuk mengembangkan kelompoknya.

Pengejawentahan modal sosial dalam ekonomi yang paling tepat, seperti dicontohkan oleh Thoby Muthis, adalah koperasi. Koperasi, seperti yang dicitacitakan oleh Bung Hatta dalam bukunya "Membangun Koperasi dan Koperasi Membangun", memiliki prinsip-prinsip yang menekankan pada kohesifitas kelompok usaha, untuk memberdayakan diri dan membangun kepercayaan (Asia Foundation, 1998). Prinsip-prinsip tersebut secara lebih lengkap adalah: (1) kebenaran untuk menggerakkan kepercayaan, (2) keadilan dalam usaha bersama, (3) kebaikan dan kejujuran mencapai perbaikan yang senantiasa, (4) tanggung jawab dalam individualitas dan solidaritas, (5) paham yang sehat, cerdas, dan tegas, (6) kemauan menolong diri sendiri dan menggerakkan otoaktivitas, (7) kesetiaan dalam pengurusan. Sementara itu dalam perkembangannya, modal sosial tersebut mengalami perkembangan seiring dengan perkembangan dengan adanya teknologi. Inilah yang oleh banyak pemikir disebut sebagai new social capital, yang salah 
satunya dicirikan dengan adanya internet dan media sosial. .

Pertumbuhan internet dengan kehadiran media sosial sekarang ini berdampak pada modal sosial, keberadaan media sosial telah membuka jaringanjaringan baru yang menawarkan begitu banyak peluang. Menurut Manuell Castells, teknologi identitas kaku modernisme, teknologi dapat membantu masyarakat untuk membangun kontak dan nilai kedalam kedirian kita dan tekonologi telah menempati posisi sentral pada ruang sosial yang membuka kesempatan yang luas pada elemen-elemen terpisah (Field, 2010). Pernyataan diatas dapat dikatakan bahwa modal sosial baru adalah modal soial yang memanfaatkan sosial virtual, yang menjadikan internet sebagai tempat bersosialisasi (Turkle dalam Field, 2010). Dikatakan pula oleh Urry (2002) bahwa orang yang sedang beinteraksi secara online adalah bagian dari penguasaan modal sosial, dimana dikatakan oleh Field (2010) bahwa internet telah mampu memberi ruang dalam modal sosial dalam era post modern atau bisa dikatan modal sosial yang baru. Internet merupakan produk teknologi yang banyak dimanfaatkan oleh masyarakat, internet juga memunculkan jenis interaksi sosial baru dalam masyarakat (Alyusi, 2016).

Menurut Tuten (2008), kehadiran internet dapat memberikan ruang bagi paraktik-praktik pemasaran, praktik ini misalanya bisa dilihat dalam iklan di Facebook. Bentuk suatu iklan yang ingin mengenalkan produk atau menjual kepada teman maupun kelompok komunitas virtual bisa berdasarkan hobby, jenis kelamin, usia yang dapat dilihat dimana saja dan kapan saja (Nasrullah, 2017).

Situs jaringan sosial merupakan situs dengan memberikan fasilitas teknologi agar pengguna dapat bersosialisasi di dunia maya, perkembangan situs online yang begitu pesat dimulai pada tahun 2003, saat itu jaringan sosial yang terkenal seperti MySpace dan Friendster (Addy Sukma Bharata dan Al Kalam, 2008).. Individu-invidu yang menggunakan internet sebagai koneksi perluasan jaringan bukanlah seorang yang tidak jujur atau hipermodernitas sedang terguncang, melainkan individu-individu yang telah banyak membangun koneksi dengan tatap muka kemudian dilengkapi dengan melakukan online di media sosial (Wellman dalam Field, 2010).

Penggunaan internet lebih banyak ikut serta dalam kegiatan sosial, selain itu pengguna internet seperti media sosial dapat mengandalkan teman atau sahabat dalam perluasan jaringan daripada harus mengandalkan keluarga (Garnerd dan Oswald dalam Field, 2010). Kehadiran internet yang telah memberikan banyak manfaat membuat para penggunanya memperluas jaringan secara online meski jarak antar para pengguna berjauhan, bahkan internet dapat memelihara ikatan yang lemah menjadi ikatan yang kuat (Wallman dalam Field, 2010). Manfaat dari media online juga dapat memberi tambahan tingkat pendapatan bagi aktor ekonomi dalam menumbuhkan modal sosial dengan komunitas online, kehadiran internet telah mengembangakan modal sosial dalam memperkaya koneksi dan jaringan pada manusia (Field, 2010).

\section{New Social Capital dan Jalan Kesuksesan Batik Tanjung Bumi}

Fukuyama menyatakan bahwa kepercayaan memerankan peran dalam aktivitas ekonomi dalam transaksi bisnis secara lebih canggih dengan teknologi (Fukuyama dalam Field, 2010). Mengakses kepercayaan juga merupakan dari jaringan sosial yang kini banyak terjadi di dunia maya yang banyak dilakukan oleh masyarakat karena dapat menghilangkan hambatan sosial seperti perbedaan ras, agama, maupun etnis (Alyusi, 2016). Modal sosial dalam dunia online dapat terjadi sebagai kecenderungan masyarakat untuk bertukar informasi antar individu maupun kelompok, bahkan dalam dunia online modal sosial memiliki tingkatan yang sangat kuat karena biasanya dalam suatu komunitas akan terjadi aktifitas-aktifitas yang biasanya direncanakan (Alyusi, 2016).

Tidak dapat dibantah bahwa UMKM adalah penyangga ekonomi di negeri ini. Dalam konteks ini, UMKM Batik Tanjung 
Bumi Bangkalan Madura adalah bagian UMKM yang selama ini menjadi fundamental ekonomi masyarakat, khususnya di daerah Bangkalan Madura. Salah satu yang menjadikan UMKM Batik Tanjung Bumi Bangjkalan Madura bisa bertahan sampai hari ini adalah kekuatan modal sosial yang mereka miliki. Sejarah, nilai, sosial, kebudayaan, kepercayaan, dan organisasi adalah kekuatan modal sosial yang dimiliki oleh mereka. Tentu hal ini menjadi kekuatan sendiri bagi masyarakat UMKM Batitk Tanjung Bumi Bangkalan Madura. Dengan kata lain, bahwa kehadiran Batik Tanjung Bumi Bangkalan Madura sebagai kekuatan ekonomi masyarakat Tanjung Bumi adalah karena kekuatan modal sosial yang mereka miliki. Tentu tanpa menafikan modal ekonomi, modal sosial ini mampu menjadi ruh bagi pembangunan masyarakat UMKM Batik Tanjung Bumi Bangkalan Madura.

Dalam perkembangannya, modal sosial yang mereka miliki berhadapan dengan revolusi industry 4.0 yang ada. Karenanya, modal sosial yang mereka miliki juga mengalami dinamika, sehingga modal sosial mereka pun berevolousi dengan waktu. Salah satunya adalah mewujud dalam dunia internet. Inilah yang dimaksud dengan modal sosial baru atau new social capital. Dalam konteks itu maka, UMKM Batik Tanjung Bumi tidak bisa menafikan kehadiran modal sosial baru. Karenanya, kemampuan dan ketangguhan dalam menghadapi era revolusi industry 4.0 ditentukan oleh bagaimana kemampuan mereka memiliki dan mengoperasikan modal sosial baru itu; internet, media sosial, facebook, Instagram, dll.

Tanpa tanggap terhadap perkembangan modal sosial baru yang ada dalam dunia global, masyarakat UMKM Batik Tanjung Bumi Bangkalan Madura akan ditinggalkan oleh pasar. Sebaliknya dengan pemanfaatan modal sosial baru yang ada UMKM Batik Tanjung Bumi akan melesat cepat.

\section{DAFTAR PUSTAKA}

Asia Foundation. 1998. Kekuatan Kolektif Sebagai Strategi Mempercepat Pemberdayaan Usaha Kecil, Prosiding Konferensi Nasional Usaha Kecil 7-8 Oktober 1998. Jakarta.

Fukuyama, F. 2000. The Great Disruption: Human Nature and The Reconstitution of Social Order. USA: Touchstone.

Fukuyam, F. 2010. "Trust". Cetakan ke 2. Penerbit Qalam. Yoyakarta.

Field, J. 2010. "Modal sosial" Kreasi Wacana. Yogyakarta.

Hidayat, H. 2001. Efektivitas Pelatihan Kapital Sosial untuk Meningkatkan Kesadaran Berbangsa, Karya tulis tidak diterbitkan, Fakultas Psikologi UGM Yogyakarta.

Moleong, L.J. 1991, Metodologi Penelitian Kualitatif. Remaja Rosdakarya. Bandung.

Miles, M.B \& M.B Huberman. 1984. Qualitative Data Analysis: A Source of New Methods. Sage Publications. London

Mubyarto, 1994, Sistem dan Moral Ekonomi Indonesia. LP3ES. Jakarta.

Nasrullah, R. 2017.Media Sosial Persepektif Komunikasi, Budaya dan Sosiotekolog. Cetakan ke 3. Simbiosa Rekatama Media. Bandung.

Taylor, et.al. 1994. Social Psychology. Prenctice Hall. New Jersey.

Woolcock. M. 1998. Social Capital and Economic Development: Towards a Theoretical Synthesis and Policy Framework. www.google.com. 
54 Jurnal Pamator 